\title{
Effect of FYM, biofertilizers and zinc on nitrogen uptake by maize crop
}

R.S. FAUJDAR AND MAHENDRA SHARMA

Received : 01.11.2014; Revised : 05.05.2015; Accepted : 16.05 .2015

MEMBERS OF RESEARCH FORUM:

Corresponding author : R.S. FAUJDAR, Department of Agricultural Chemistry and Soil Science, Rajasthan College of Agriculture, M.P. University of Ag. \& Tech., UDAIPUR (RAJASTHAN) INDIA

Email: rohit_faujdar99@yahoo.co.in

Co-authors :

MAHENDRA SHARMA, Department of Agricultural Chemistry and Soil Science, Rajasthan College of Agriculture, M.P. University of Ag. \& Tech., UDAIPUR (RAJASTHAN) INDIA

\section{Summary}

A field experiment was conducted to study the effect of FYM, biofertilizers (Azotobacter and VAM) and zinc on uptake of nitrogen by maize during two consecutive years of 2006-07 and 2007-08 at Instructional Farm, Rajasthan College of Agriculture, Maharana Pratap University of Agriculture and Technology, Udaipur. Application of FYM, biofertilizers and zinc significantly increased nitrogen uptake by maize. Combined use of FYM and biofertilizers significantly increased nitrogen uptake by maize and combined use of FYM and $\mathrm{Zn}$ also significantly increased the nitrogen uptake by maize.

Key words : FYM, Biofertilizers, Zinc, Maize, Nitrogen, Uptake

How to cite this article : Faujdar, R.S. and Sharma, Mahendra (2015). Effect of FYM, biofertilizers and zinc on nitrogen uptake by maize crop. Asian J. Soil Sci., 10(1) : 125-129. 